\title{
Streptomyces tacrolimicus sp. nov., a low producer of the immunosuppressant tacrolimus (FK506)
}

\author{
Correspondence \\ Juan F. Martín \\ jf.martin@unileon.es
}

\author{
Miriam Martínez-Castro, ${ }^{1}$ Carlos Barreiro, ${ }^{2}$ Francisco Romero, ${ }^{3}$ \\ Rosa Isabel Fernández-Chimeno ${ }^{3}$ and Juan F. Martín ${ }^{1,2}$ \\ ${ }^{1}$ Área de Microbiología, Dpto. de Biología Molecular, Fac. CC. Biológicas y Ambientales, Campus de \\ Vegazana s/n, Universidad de León, 24071 León, Spain \\ ${ }^{2}$ Instituto de Biotecnología de León (INBIOTEC), Parque Científico de León, Avda. Real, no. 1, \\ 24006 León, Spain \\ ${ }^{3}$ Instituto Biomar, S.A., Parque Tecnológico de León, 24009 Armunia, León, Spain
}

Species of the genus Streptomyces have been an excellent source of clinically and industrially relevant compounds because their genomes contain a large number of gene clusters that encode secondary metabolites (Bentley et al., 2002; Ikeda et al., 2003; Ohnishi et al., 2008). The macrolide tacrolimus (FK506), discovered by Kino et al. (1987), was the first of a new family of immunosuppressants that are used in the treatment of graft rejection after organ transplantation. Initially, tacrolimus was detected in a fermentation broth of 'Streptomyces tsukubaensis' and other tacrolimus-producing strains of the genus Streptomyces have been discovered since then, for example strain ATCC $55098^{\mathrm{T}}$ (Dumont et al., 1992), strain ATCC 53770 (Garrity et al., 1993), strain MA 6949 (Sigmund et al., 2003) and Streptomyces clavuligerus CKD1119 (Kim \& Park, 2008). Phylogenetic studies have been performed for some of the strains that produce tacrolimus and related compounds (Garrity et al., 1993, Muramatsu et al., 2005) and have shown an apparent

Abbreviations: DAP, diaminopimelic acid; ISP, International Streptomyces Project.

The GenBank/EMBL/DDBJ accession number for the 16S rRNA gene sequence of strain ATCC $55098^{\top}$ is FN429653. lack of genetic relationships between them, despite sharing the same cluster of tacrolimus-biosynthesis genes. Part of the gene cluster for the biosynthesis of tacrolimus has been reported in strain ATCC $55098^{\mathrm{T}}$, but there is no effective taxonomic description of this strain.

There are more than 500 recognized species and subspecies in the genus Streptomyces (Euzéby, 1997), and the large number of strains has made the taxonomy of this genus difficult. In 1964, the International Streptomyces Project (ISP) was established to classify authentic type strains of species of the genus using a relatively small number of traditional tests. This system defined the basis of Streptomyces systematics but showed some limitations, which have been solved by a polyphasic approach. The combination of genotypic and phenotypic features provides useful information for the classification of this complex group of bacteria. The present study was designed to determine the taxonomic position of the tacrolimusproducing strain ATCC $55098^{\mathrm{T}}$. Strain ATCC $55098^{\mathrm{T}}$ was obtained from the American Type Culture Collection. This strain was isolated from dung of white-tailed deer in Poverty Creek Drainage, Montgomery County, VA, USA (Dumont et al., 1992). 
Morphological characterization of strain ATCC $55098^{\mathrm{T}}$ was performed following the standard ISP protocol (Shirling \& Gottlieb, 1966). Sporulation, aerial spore-mass colour, substrate mycelium pigmentation and production of diffusible pigments were observed on different agar media following incubation at $28{ }^{\circ} \mathrm{C}$ for 14 days. Colours were described according to the ISCC-NBS colour charts (Kelly, 1964). Microscopic observation of hyphal and spore chain arrangements was performed by scanning electron microscopy (JEOL 6100) of 14-day-old cultures grown on ISP 2 medium at $28{ }^{\circ} \mathrm{C}$.

Physiological characteristics were determined following the methods described by Shirling \& Gottlieb (1966) and Williams et al. (1983) and were recorded after 14 days of incubation at $28{ }^{\circ} \mathrm{C}$, except where specified. Growth with 1 , 2, 3, 5, 7 and $10 \%(\mathrm{w} / \mathrm{v}) \mathrm{NaCl}$ was tested on 172 medium [containing $\left(1^{-1}\right) 10 \mathrm{~g}$ glucose, $20 \mathrm{~g}$ glucidex-20, $5 \mathrm{~g}$ yeast extract, $5 \mathrm{~g}$ casein peptone and $1.8 \mathrm{~g}$ agar, adjusted to $\mathrm{pH} 6.8$ and then supplemented with $8 \mathrm{~g} \quad \mathrm{CaCO}_{3}$ ]. Antibiotic sensitivity of strain ATCC $55098^{\mathrm{T}}$ and its closest phylogenetic neighbours was tested on modified Bennett's agar (MBA; Jones, 1949) with different antibiotic concentrations at $28{ }^{\circ} \mathrm{C}$ for 7 days.

Fatty acid analysis was carried out using mycelium grown on solid medium. Strain ATCC $55098^{\mathrm{T}}$ was cultured on 172 medium at $28{ }^{\circ} \mathrm{C}$ for 7 days and then on $172 \mathrm{~A}$ agar [containing $\left(1^{-1}\right) 10 \mathrm{~g}$ glucose, $20 \mathrm{~g}$ glucidex-20, $5 \mathrm{~g}$ yeast extract, $5 \mathrm{~g}$ casein peptone, $2.5 \mathrm{~g}$ MOPS and $1.8 \mathrm{~g}$ agar; $\mathrm{pH}$ 7.2] at $28{ }^{\circ} \mathrm{C}$ for another 7 days. Analysis of the fatty acid composition was performed with an Agilent 5898A gas chromatograph using an Ultra2 capillary column as described by Miller (1982) with the modifications of Miller \& Berger (1985). The whole-cell sugar composition was determined by TLC following the procedure described by Hasegawa et al. (1983). Analysis of the isomer of diaminopimelic acid (DAP) was performed by TLC with ninhydrin staining by the following method. Liquid culture $(2 \mathrm{ml})$ was centrifuged at 3000 r.p.m. for $10 \mathrm{~min}$. The pellet was washed twice by resuspension in $2 \mathrm{ml} 8 \%$ SDS, sonication for $10 \mathrm{~min}$ in a sonicator bath and centrifugation and then washed with $8 \mathrm{ml}$ distilled water and centrifuged for $5 \mathrm{~min}$. The suspension was hydrolysed with sulfuric acid following the indications of Becker et al. (1964) and neutralized with a saturated solution of $\mathrm{Ba}(\mathrm{OH})_{2}$. The supernatant fluid was evaporated and the residue was redissolved in $0.3 \mathrm{ml}$ distilled water. TLC was performed as described by Staneck \& Roberts (1974). The $\mathrm{G}+\mathrm{C}$ content of the genomic DNA was determined by HPLC (Agilent 1100) following the procedure described by Tamaoka \& Komagata (1984).

For 16S rRNA gene sequence analysis, genomic DNA of strain ATCC $55098^{\mathrm{T}}$ was isolated by the salting-out method (Kieser et al., 2000) and the 16S rRNA gene was amplified using primers that corresponded to conserved regions of the gene sequence in other Streptomyces species and which were designed to incorporate restriction sites (16S-ClaI,
5'-ACATCGATGACGCTGTGAAC-3'; 16S-XbaI, 5'-GTGATCTAGACGCACCTTCC-3'). PCR was performed with a high-fidelity $P f x$ polymerase (Invitrogen), with the following conditions: $96{ }^{\circ} \mathrm{C}$ for $30 \mathrm{~s}, 67^{\circ} \mathrm{C}$ for $30 \mathrm{~s}$ and $72{ }^{\circ} \mathrm{C}$ for $100 \mathrm{~s}$. The amplification products were separated using gel electrophoresis, excised from the gel and purified using the GFX PCR DNA and Gel Band Purification kit (GE Healthcare). The purified fragments were cloned into the pBluescript $\mathrm{SK}^{+}$plasmid (Stratagene). The $16 \mathrm{~S}$ rRNA gene was sequenced using a ABI Prism 3130 Genetic Analyzer (Applied Biosystems). A preliminary sequence analysis was performed using the BLAST network service provided by the European Bioinformatic Institute (EBI) and showed similarity between strain ATCC $55098^{\mathrm{T}}$ and many members of the genus Streptomyces. For phylogenetic analysis, type strains of species of the genus Streptomyces that showed $\geqslant 98 \% 16 \mathrm{~S}$ rRNA gene sequence similarity with strain ATCC $55098^{\mathrm{T}}$ were selected. Sequences were aligned using CLUSTAL W (Thompson et al., 1994). Phylogenetic trees were generated according to neighbour-joining (Saitou \& Nei, 1987) and maximum-likelihood (Felsenstein, 1981) methods in PHYLIP 3.65 (Felsenstein, 2005) and MEGA4 (Tamura et al., 2007), respectively. The evolutionary distance matrix for the neighbour-joining algorithm was calculated with Kimura's two-parameter correction model (Kimura, 1980). The topologies of the resultant trees were evaluated by bootstrap analysis (Felsenstein, 1985) with 1000 replicates.

DNA-DNA relatedness was determined between strain ATCC $55098^{\mathrm{T}}$ and its two closest phylogenetic neighbours. Genomic DNA was isolated using a French pressure cell (Thermo Spectronic) and purified by chromatography on hydroxyapatite as described by Cashion et al. (1977). DNA-DNA hybridization was carried out following the procedure of De Ley et al. (1970) with the modifications described by Huß et al. (1983) using a Cary 100 Bio UV/Vis spectrophotometer equipped with a Peltier-thermostatted $6 \times 6$ multicell changer and a temperature controller with an in situ temperature probe (Varian).

The phenotypic characteristics of strain ATCC $55098^{\mathrm{T}}$ are compared with those of its closest phylogenetic neighbours in Table 1. The morphological and chemical properties of strain ATCC $55098^{\mathrm{T}}$ are in concordance with its inclusion in the genus Streptomyces, although there were differences in morphological features between the isolate and its closest phylogenetic neighbours. Strain ATCC $55098^{\mathrm{T}}$ grew well on yeast extract-malt extract agar (ISP 2), oatmeal agar (ISP 3), inorganic salts-starch agar (ISP 4) and glycerol-asparagine agar (ISP 5). Sporulation was produced on all ISP media after 14 days of incubation, but diffusible pigments were not produced. Melanin was not produced on peptone-yeast extract-iron agar (ISP 6) or tyrosine agar (ISP 7). Morphological observation of 14-day-old cultures grown on ISP 2 medium revealed a branched mycelium without verticils. The aerial mycelium consisted of flexuous chains of short rod-shaped and warty-surfaced spores (Fig. 1). 
Table 1. Phenotypic characteristics that differentiate strain ATCC $55098^{\top}$ from its closest phylogenetic neighbours

Strains: 1, Streptomyces tacrolimus sp. nov. ATCC $55098^{\mathrm{T}}$; 2, S. fulvissimus DSM $40593^{\mathrm{T}}$; 3, S. flavofungini DSM $40366^{\mathrm{T}}$. Data were taken from this study. All of the strains utilized D-glucose, D-mannitol and D-mannose $(1 \% \mathrm{w} / \mathrm{v})$ as sole carbon sources, assimilated L-valine, L-cysteine, L-histidine, L-phenylalanine and L-threonine $(0.1 \% \mathrm{w} / \mathrm{v})$ as sole nitrogen sources, grew at $\mathrm{pH} 5-9$ and $16-30{ }^{\circ} \mathrm{C}$ and were resistant to $\left(\mu \mathrm{g} \mathrm{ml}^{-1}\right)$ penicillin $\mathrm{G}$ (100), ampicillin (100) and tacrolimus (100). None of the strains produced melanin on ISP 7, used DL-2-aminobutyric acid as a sole nitrogen source, grew at $4{ }^{\circ} \mathrm{C}$ or was resistant to $\left(\mu \mathrm{g} \mathrm{ml}^{-1}\right)$ kanamycin sulfate (10), apramycin (10) or gentamicin sulfate (10).

\begin{tabular}{|c|c|c|c|}
\hline Characteristic & 1 & 2 & 3 \\
\hline \multicolumn{4}{|l|}{ Sporulation on: } \\
\hline ISP 2 & Good & Good & Moderate \\
\hline ISP 3 & Good & Poor & Poor \\
\hline ISP 4 & Good & Good & Moderate \\
\hline ISP 5 & Good & Good & Absent \\
\hline \multicolumn{4}{|l|}{ Colour of aerial spore/substrate mycelium on: ${ }^{*}$} \\
\hline ISP 2 & $\mathrm{YG} / \mathrm{LO}$ & $\mathrm{LP}-\mathrm{VO} / \mathrm{SO}$ & BYG/LYG \\
\hline ISP 3 & $\mathrm{YW} / \mathrm{YW}$ & None/MR & None/Yw \\
\hline ISP 4 & Yw/LO & $\mathrm{VO}-\mathrm{YP}-\mathrm{W} / \mathrm{MO}$ & W/PYG \\
\hline ISP 5 & $\mathrm{YW} / \mathrm{YW}$ & PO-YP/DO & None/PYG \\
\hline Melanin production on ISP 6 & - & + & - \\
\hline \multicolumn{4}{|l|}{ Assimilation of sole carbon sources $(1 \%, \mathrm{w} / \mathrm{v}) \dagger$} \\
\hline L-Arabinose & - & + & \pm \\
\hline D-Fructose & \pm & + & \pm \\
\hline Lactose & \pm & - & \pm \\
\hline Maltose & - & \pm & \pm \\
\hline D-Rhamnose & + & - & - \\
\hline Sucrose & - & \pm & - \\
\hline Assimilation of L-hydroxyproline as sole nitrogen source $\ddagger$ & - & + & + \\
\hline Maximum $\mathrm{NaCl}$ concentration for growth (\%) & 10 & 7 & 7 \\
\hline Growth at $37{ }^{\circ} \mathrm{C}$ & - & + & + \\
\hline \multicolumn{4}{|l|}{ Resistance to $\left(\mu \mathrm{g} \mathrm{ml}^{-1}\right)$ : } \\
\hline Novobiocin $(100)$ & + & - & - \\
\hline Thiostrepton (20) & - & + & + \\
\hline Rifampicin (20) & - & + & - \\
\hline Streptomycin (20) & - & + & - \\
\hline Chloramphenicol (20) & - & + & + \\
\hline Chlortetracycline (20) & - & + & + \\
\hline Tetracycline (20) & - & + & + \\
\hline
\end{tabular}

${ }^{*}$ BYG, Brilliant yellow green; DO, deep orange; LO, light olive; LP, light pink; LYG, light yellow green; MO, moderate orange; MR, moderate red; PO, pale orange; PYG, pale yellowish green; SO, strong orange; vO, vivid orange; w, white; YG, yellowish grey; YP, yellowish pink; YW, yellowish white. $\dagger+$, Positive, growth with carbon source is significantly better than without, but somewhat less than with, glucose; \pm , doubtful, growth with carbon source is only slightly better than without, and significantly less than with, glucose; - , negative, growth with carbon source is similar to or less than in its absence.

¥L-Asparagine was used as the growth control, as recommended by Langham et al. (1989).

Chemotaxonomic analysis of strain ATCC $55098^{\mathrm{T}}$ showed that the cell wall contained trace levels of LLDAP but not the meso isomer. This trait, together with the lack of diagnostic sugars, is in accordance with the classification of the isolate to the cell-wall type I group (Lechevalier \& Lechevalier, 1970). The most important fatty acids in the equivalent chain-length range of $\mathrm{C}_{12}$ $\mathrm{C}_{18}$ were iso- $\mathrm{C}_{14: 0}(16.8 \%)$, iso- $\mathrm{C}_{16: 0}(12.5 \%)$, iso- $\mathrm{C}_{15: 0}$ $(12.3 \%)$, anteiso- $\mathrm{C}_{15: 0}(11.4 \%), \mathrm{C}_{16: 0}(3.4 \%), \mathrm{C}_{12: 0}$ (2.1\%), $\mathrm{C}_{16: 1}$ cis-9 $(1.3 \%)$, iso- $\mathrm{C}_{17: 0}(1.3 \%)$, anteiso$\mathrm{C}_{17: 0}(1.2 \%)$, iso- $\mathrm{C}_{16: 1}(1.0 \%)$ and $\mathrm{C}_{17: 0}$ cyclo $(1.0 \%)$. This composition is characteristic of the genus Streptomyces, where the most important fatty acids are of the iso- and anteiso-branched types as well as saturated straight-chain fatty acids (Locci, 1989). The fatty acid profile indicated that strain ATCC $55098^{\mathrm{T}}$ is a member of the genus Streptomyces. The DNA G $+\mathrm{C}$ content of strain ATCC $55098^{\mathrm{T}}$ was $71 \mathrm{~mol} \%$.

A 1629 bp fragment of the 16S rRNA gene sequence of strain ATCC $55098^{\mathrm{T}}$ was obtained. The neighbour-joining phylogenetic tree based on almost-complete (1469 bp) $16 \mathrm{~S}$ rRNA gene sequences of the isolate and closely related type strains of species of the genus Streptomyces indicated that strain ATCC $55098^{\mathrm{T}}$ formed a separate branch adjacent to a cluster that comprised Streptomyces fulvissimus NBRC 


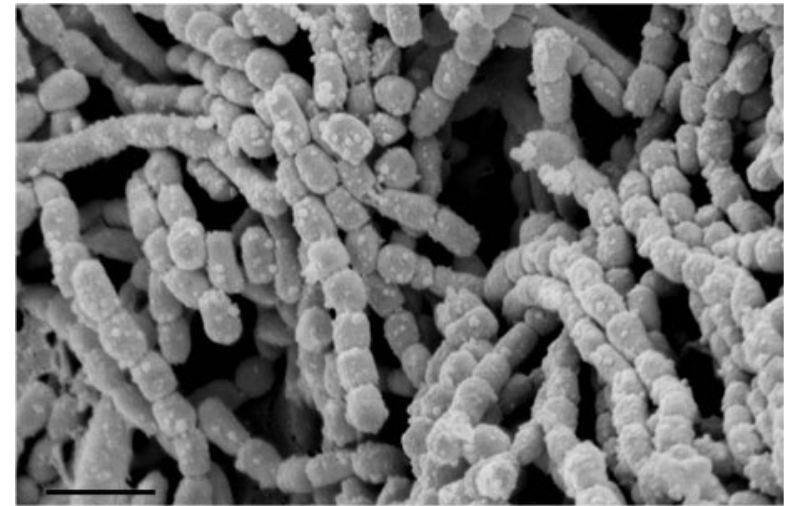

Fig. 1. Scanning electron micrograph of spores of strain ATCC $55098^{\top}$ after growth on yeast extract/malt extract agar (ISP 2) for 14 days at $28^{\circ} \mathrm{C}$. Bar, $2 \mu \mathrm{m}$.

$13482^{\mathrm{T}}$ and Streptomyces flavofungini NBRC $13371^{\mathrm{T}}$ (Fig. 2). In the maximum-likelihood tree, the isolate formed a distinct lineage that was not included in any group. The highest 16S rRNA gene sequence similarities were observed between strain ATCC $55098^{\mathrm{T}}$ and S. fulvissimus NBRC $13482^{\mathrm{T}}(98.6 \%)$ and S. flavofungini NBRC $13371^{\mathrm{T}}$ $(98.4 \%)$.

DNA-DNA relatedness between strain ATCC $55098^{\mathrm{T}}$ and S. fulvissimus DSM $40593^{\mathrm{T}}$ and S. flavofungini DSM $40366^{\mathrm{T}}$ was 31.5 and $14.5 \%$, respectively. These values were well below the $70 \%$ cut-off point recommended for the separation of genomic species (Wayne et al., 1987) and indicated that strain ATCC $55098^{\mathrm{T}}$ is a member of a novel species.

On the basis of phenotypic, phylogenetic and chemotaxonomic analysis, we propose that strain ATCC $55098^{\mathrm{T}}$ represents a novel species of the genus Streptomyces, for which the name Streptomyces tacrolimicus sp. nov. is proposed. Strain ATCC $55098^{\mathrm{T}}$ is a less-efficient tacrolimus producer than ' $S$. tsukubaensis' under the same fermentation conditions, as measured by HPLC with a method based on that of Shafiee et al. (1994).

\section{Description of Streptomyces tacrolimicus sp. nov.}

Streptomyces tacrolimicus (ta.cro.li'mi.cus. N.L. neut. n. tacrolimun tacrolimus; L. suff. icus -a -um related to; N.L. masc. adj. tacrolimicus related to tacrolimus, referring to the type strain's ability to produce tacrolimus).

Aerobic actinomycete that develops an extensively branched substrate mycelium and aerial hyphae, which differentiate into flexuous chains of short rod-shaped and warty-surfaced spores. Yellowish grey to yellowish white aerial spore mass and light olive to yellowish white substrate mycelium are formed on ISP media. Does not produce diffusible pigments or melanin pigments on peptone-yeast extract-iron agar or tyrosine agar. Growth occurs at $16-30{ }^{\circ} \mathrm{C}$, at $\mathrm{pH} 5-9$ and with $10 \%(\mathrm{w} / \mathrm{v}) \mathrm{NaCl}$. As sole carbon sources for energy and growth, D-glucose, D-mannitol, D-mannose, D-fructose, lactose and D-rhamnose (each at $1 \%, \mathrm{w} / \mathrm{v}$ ) are used, but L-arabinose, maltose and sucrose are not. As sole nitrogen sources for energy and growth, L-valine, L-cysteine, L-histidine, L-phenylalanine, L-threonine and L-asparagine (each at $0.1 \%, \mathrm{w} / \mathrm{v}$ ) are used, but DL-2-aminobutyric acid and L-hydroxyproline are not. Additional phenotypic characteristics are shown in Table 1. The cell wall contains LL-DAP. Chemotaxonomic characteristics are typical of the genus Streptomyces. The DNA G $+\mathrm{C}$ content of the type strain is $71 \mathrm{~mol} \%$.

The type strain, ATCC $55098^{\mathrm{T}}\left(=\mathrm{CECT} 7664^{\mathrm{T}}\right)$, was isolated from the dung of white-tailed deer in Virginia, USA, and produces a small amount of the immunosuppressant tacrolimus.

\section{Acknowledgements}

This work was supported by a grant of the Ministry of Education and Science, Spain (grant no. BIO2006-14853-C02-01), and a grant of Grupo de Excelencia of the Junta de Castilla y León (grant no. GR117). M. M.-C. received a fellowship of the Ministry of Education and Innovation of Spain (MICINN). C. B. was supported by the Programa de Personal Técnico de Apoyo of the MICINN and the European Social Fund (ESF) (grant no. PTA-2003-01-00689). We thank P. Garcia (Área de Genética, Universidad de León, Spain) and

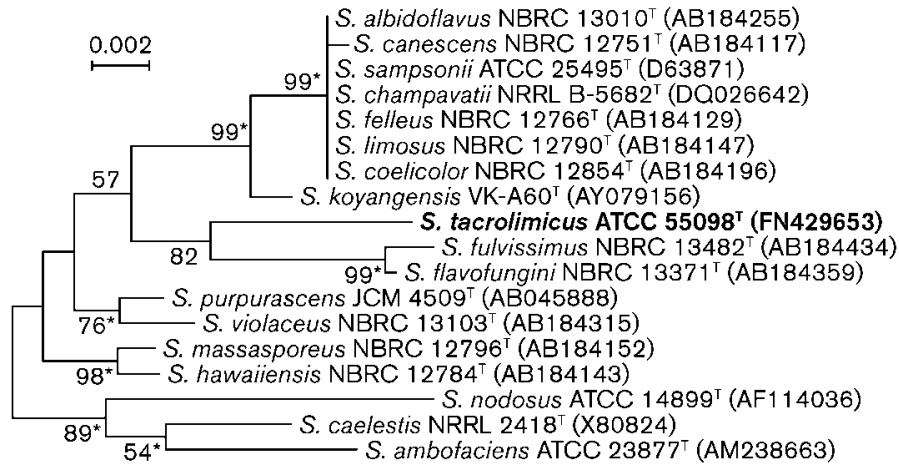

Fig. 2. Neighbour-joining phylogenetic tree based on almost-complete (1469 bp) 16S rRNA gene sequences showing the relationships between strain ATCC $55098^{\top}$ and closely related type strains of species of the genus Streptomyces. Bootstrap values $(>50 \%)$ based on 1000 replicates are shown at branch nodes. Asterisks indicate that the corresponding nodes were also recovered in the tree generated using the maximum-likelihood algorithm. Bar, 0.002 substitutions per nucleotide position. 
E. Garay (Universidad de Valencia, Spain) for their scientific support and J. Merino, B. Martín, A. Casenave and A. Mulero for excellent technical assistance.

\section{References}

Becker, B., Lechevalier, M. P., Gordon, R. E. \& Lechevalier, H. A. (1964). Rapid differentiation between Nocardia and Streptomyces by paper chromatography of whole-cell hydrolysates. Appl Microbiol 12, 421-423.

Bentley, S. D., Chater, K. F., Cerdeño-Tárraga, A. M., Challis, G. L., Thomson, N. R., James, K. D., Harris, D. E., Quail, M. A., Kieser, H. \& other authors (2002). Complete genome sequence of the model actinomycete Streptomyces coelicolor A3(2). Nature 417, 141-147.

Cashion, P., Holder-Franklin, M. A., McCully, J. \& Franklin, M. (1977). A rapid method for the base ratio determination of bacterial DNA. Anal Biochem 81, 461-466.

De Ley, J., Cattoir, H. \& Reynaerts, A. (1970). The quantitative measurement of DNA hybridization from renaturation rates. Eur J Biochem 12, 133-142.

Dumont, F., Garrity, G. M., Fernandez, I. M. \& Matas, T. D. (1992). Process for producing FK506. United States patent no. 5,116,756.

Euzéby, J. P. (1997). List of bacterial names with standing in nomenclature: a folder available on the Internet. Int J Syst Bacteriol 47, 590-592.

Felsenstein, J. (1981). Evolutionary trees from DNA sequences: a maximum likelihood approach. J Mol Evol 17, 368-376.

Felsenstein, J. (1985). Confidence limits on phylogenies: an approach using the bootstrap. Evolution 39, 783-791.

Felsenstein, J. (2005). PHYLIP (phylogeny inference package) version 3.6. Distributed by the author. Department of Genome Sciences, University of Washington, Seattle.

Garrity, G. M., Heimbuch, B. K., Motamedi, H. \& Shafiee, A. (1993). Genetic relationships among actinomycetes that produce the immunosuppressant macrolides FK506, FK520/FK523 and rapamycin. J Ind Microbiol 12, 42-47.

Hasegawa, T., Takizawa, M. \& Tanida, S. (1983). A rapid analysis for chemical grouping of aerobic actinomycetes. J Gen Appl Microbiol 29, 319-322.

Huß, V. A. R., Festl, H. \& Schleifer, K. H. (1983). Studies on the spectrophotometric determination of DNA hybridization from renaturation rates. Syst Appl Microbiol 4, 184-192.

Ikeda, H., Ishikawa, J., Hanamoto, A., Shinose, M., Kikuchi, H., Shiba, T., Sakaki, Y., Hattori, M. \& Omura, S. (2003). Complete genome sequence and comparative analysis of the industrial microorganism Streptomyces avermitilis. Nat Biotechnol 21, 526-531.

Jones, K. L. (1949). Fresh isolates of actinomycetes in which the presence of sporogenous aerial mycelia is a fluctuating characteristic. J Bacteriol 57, 141-145.

Kelly, K. L. (1964). Inter-Society Color Council - National Bureau of Standards Color Name Charts Illustrated with Centroid Colors. Washington, DC: US Government Printing Office.

Kieser, T., Bibb, M. J., Buttner, M. J., Chater, K. F. \& Hopwood, D. A. (2000). Practical Streptomyces Genetics. Norwich: John Innes Foundation.

Kim, H. S. \& Park, Y. I. (2008). Isolation and identification of a novel microorganism producing the immunosuppressant tacrolimus. J Biosci Bioeng 105, 418-421.

Kimura, M. (1980). A simple method for estimating evolutionary rates of base substitutions through comparative studies of nucleotide sequences. J Mol Evol 16, 111-120.
Kino, T., Hatanaka, H., Hashimoto, M., Nishiyama, M., Goto, T., Okuhara, M., Kohsaka, M., Aoki, H. \& Imanaka, H. (1987). FK-506, a novel immunosuppressant isolated from a Streptomyces. I. Fermentation, isolation, and physico-chemical and biological characteristics. J Antibiot (Tokyo) 40, 1249-1255.

Langham, C. D., Williams, S. T., Sneath, P. H. A. \& Mortimer, A. M. (1989). New probability matrices for identification of Streptomyces. J Gen Microbiol 135, 121-133.

Lechevalier, M. P. \& Lechevalier, H. (1970). Chemical composition as a criterion in the classification of aerobic actinomycetes. Int J Syst Bacteriol 20, 435-443.

Locci, R. (1989). Streptomyces and related genera. In Bergey's Manual of Systematic Bacteriology, vol. 4, pp. 2451-2508. Edited by S. T. Williams, M. E. Sharpe \& J. G. Holt. Baltimore: Williams \& Wilkins.

Miller, L. T. (1982). Single derivatization method for routine analysis of bacterial whole-cell fatty acid methyl esters, including hydroxy acids. J Clin Microbiol 16, 584-586.

Miller, L. \& Berger, T. (1985). Bacteria identification by gas chromatography of whole cell fatty acids, Hewlett-Packard application note 228-241. Avondale, PA: Hewlett-Packard.

Muramatsu, H., Mokhtar, S., Katsuoka, M. \& Ezaki, M. (2005). Phylogenetic analysis of immunosuppressant FK506-producing streptomycete strains. Actinomycetologica 19, 33-39.

Ohnishi, Y., Ishikawa, J., Hara, H., Suzuki, H., Ikenoya, M., Ikeda, H., Yamashita, A., Hattori, M. \& Horinouchi, S. (2008). Genome sequence of the streptomycin-producing microorganism Streptomyces griseus IFO 13350. J Bacteriol 190, 4050-4060.

Saitou, N. \& Nei, M. (1987). The neighbor-joining method: a new method for reconstructing phylogenetic trees. Mol Biol Evol 4, 406425.

Shafiee, A., Motamedi, H. \& Chen, T. (1994). Enzymology of FK-506 biosynthesis. Purification and characterization of 31-O-desmethylFK506 O: methyltransferase from Streptomyces sp. MA6858. Eur J Biochem 225, 755-764.

Shirling, E. B. \& Gottlieb, D. (1966). Methods for characterization of Streptomyces species. Int J Syst Bacteriol 16, 313-340.

Sigmund, J. M., Clark, D. C., Rainey, F. A. \& Anderson, A. S. (2003). Detection of eubacterial 3-hydroxy-3-methylglutaryl coenzyme a reductases from natural populations of actinomycetes. Microb Ecol 46, 106-112.

Staneck, J. L. \& Roberts, G. D. (1974). Simplified approach to identification of aerobic actinomycetes by thin-layer chromatography. Appl Microbiol 28, 226-231.

Tamaoka, J. \& Komagata, K. (1984). Determination of DNA base composition by reversed-phase high-performance liquid chromatography. FEMS Microbiol Lett 25, 125-128.

Tamura, K., Dudley, J., Nei, M. \& Kumar, S. (2007). MEGA4: molecular evolutionary genetics analysis (MEGA) software version 4.0. Mol Biol Evol 24, 1596-1599.

Thompson, J. D., Higgins, D. G. \& Gibson, T. J. (1994). ClusTAL W: improving the sensitivity of progressive multiple sequence alignment through sequence weighting, position-specific gap penalties and weight matrix choice. Nucleic Acids Res 22, 4673-4680.

Wayne, L. G., Brenner, D. J., Colwell, R. R., Grimont, P. A. D., Kandler, O., Krichevsky, M. I., Moore, L. H., Moore, W. E. C., Murray, R. G. E. \& other authors (1987). International Committee on Bacterial Systematics. Report of the ad hoc committee on reconciliation of approaches to bacterial systematics. Int J Syst Bacteriol 37, 463-464.

Williams, S. T., Goodfellow, M., Alderson, G., Wellington, E. M., Sneath, P. H. \& Sackin, M. J. (1983). Numerical classification of Streptomyces and related genera. J Gen Microbiol 129, 1743-1813. 